\title{
Peningkatan Kemampuan Keuangan Dan Profesionalisme Pengelolaan Usaha Di Kelompok Usaha "Kartini"
}

\author{
Niniek Imaningsih ${ }^{1^{*}}$, Mohammad Wahed ${ }^{2}$ \\ 1,2Universitas Pembangunan Nasional "Veteran" Jawa Timur \\ ${ }^{*}$ Corresponding author \\ E-mail: ninieki.ep@upnjatim.ac.id
}

\section{Article History:}

Received: 27-10-2020

Revised: 21-11-2020

Accepted: 19-04-2021

Keywords:

\begin{abstract}
Kelompok usaha atau UKM "Kartini" yang terdiri dari ibu-ibu rumah tangga yang mencari pendapatan tambahan guna untuk membantu para suami, memiliki peluang usaha yang sangat bagus. Karena produk yang dihasilkan adalah produk olahan makanan yang bergizi dan sehat dengan harga yang terjangkau. Kelompok usaha "Kartini" ini telah berdiri selama 2 tahun. Kelompok Ibu-lbu ini setiap harinya membuat makanan kudapan dan minuman dengan bahan pangan lokal. Didasarkan hasil dari pengamatan untuk pengelolaan keuangan aliran kas dan keuangan penjualan yang telah dilakukan oleh Kelompok usaha "Kartini" masih masih dihadapkan dengan berbagai permasalahan, diantaranya: 1) manajemen Usaha yang kurang tertata dengan baik; dan 2) sistem pencatatan keuangan usaha yang belum teratur dan rapi. Persepsi pelaku UKM "Kartini" terhadap penggunaan/fungsi dari manajemen keuangan terbilang cukup rendah, fakta ini dibenarkan dari hasil lapangan yang menemukan bahwa kelompok usaha "kartini" belum melakukan pencatatan keuangan secara baik dan benar sesuai dengan standar yang ada mulai dari pencatatan penerimaan, pencatatan pengeluaran, penyusunan laporan laba rugi, dan pencatatan penerimaan/pengeluaran kas. Sedangkan faktor modal yang minim, persaingan yang ketat antar pelaku usaha, tempat usaha yang belum memadai menjadi penghambat utama dari kinerja kelompok usaha "kartini" selama ini. Disamping itu, hasil evaluasi setelah dilakukan kegiatan pendampingan pada kelompok usaha "Kartini" para anggota sudah mengerti dan mampu melakukan manajemen keuangan dengan baik dan benar, misalnya: 1) menghitung harga pokok penjualan, 2) melakukan pencatatan/pembukuan setiap transaksi; 3) membuat laporan keuangan sederhana (pencatatan secara manual); dan 4) menerapkan software keuangan yang sangat praktis dengan nama Warung Umat.

Pengelolaan Usaha, Keuangan, UKM Kartini
\end{abstract}

\section{Pendahuluan}

Era Globalisasi selalu membawa dampak positif bagi kehidupan masyarakat di Negara berkembang khususnya Indonesia jika masyarakatnya mampu melakukan persaingan dalam berbagai bidang kehidupan yang sesuai dengan keadaan. Dalam perkembangannya pembangunan ekonomi nasional saat ini sudah terbilang maju, hal ini bisa dilihat dari berkembangnya perangkat teknologi yang sudah memenuhi dari berbagai aspek kehidupan masyarakat saat ini. Dalam konteks kehidupan masyarakat modern dengan karakteristik penduduk yang selalu berorientasi pada 
pengembangan keilmuan dan teknologi akan berdampak positif terhadap kehidupan masyarakat secara luas. Namu kenyataanya, hal tersebut hanya berlaku pada sekelompok masyarakat kecil saja, sehingga dampak kemajuan dari perubahan tersebut cenderung lambat, ditambah lagi faktor pendidikan masih rendah yang menyebabkan pola pikir masyarakat belum siap dengan persaingan khususnya dalam bidang ekonomi. Kondisi sosial diatas merupakan salah satu penyebab utama masih tingginya angka kemiskinan, terjadinya Trade-Off dari kebutuhan yang selalu meningkat dan daya saing selalu meningkat, namun kemampuan dalam berfikir dan pengembangan keilmuan masih belum ada peningkatan yang signifikan.

Di era modern seperti sekarang ini tuntutan keilmuan dan keterampilan merupakan hal wajib yang harus dipenuhi oleh masyarakat/penduduk dalam menghadapi persaingan di berbagai bidang, ekonomi, sosial, dan politik. Dalam bidang ekonomi, jika diperhatikan perkembangannya saat ini sudah cukup banyak usaha kecil menengah yang diprakarsai oleh kalangan ibu rumah tangga dengan berbagai macam motivasi, diantaranya keinginan membantu para suami dalam mencari kebutuhan keuangan, sehingga dapat bertahan dalam kehidupan. Salah satunya adalah ibu-ibu yang tergabung dalam kelompok usaha "Kartini", dimana kelompok ini adalah menghimpun beberapa ibu-ibu yang berada didaerah keputeran untuk dapat mengembangan kemampuannya dalam menghasilkan suatu produk olahan makanan, diantaranya adalah aneka macam kue basah, masakan rumahan dan aneka jenis kue kering. Kelompok usaha "Kartini" ini diketuai oleh seorang ibu yang sangat peduli dengan sekitarnya yaitu Erni Imayani. Kelompok usaha "Kartini" terletak di daerah Keputran. Selama kegiatan kelompok usaha ini mendapatkan omset dari hasil penjualannya sekitar 1.500.000-2.000.000 per bulan. Jika dilihat dari hasil yang didapatkan keuntungan bersih yang didapatkan sangatlah besar, namun terkadang dalam melakukan proses pembukuan hasil penjualan dan pencatatan pesanan serta pengeluaran yang ada pada kelompok usaha ini masihlah sangat minim.

Sehingga jika kelompok tersebut mendapatkan pesanan yang besar mereka terkadang akan menolak karena kurangnya pengetahuan dan kemampuan mereka dalam mengelola usaha dengan baik terutama dalam hal perencanaan kegiatan dan keuangan. Padahal potensi dan kemampuan para ibu-ibu yang tergabung dalam kelompok ini dalam hal pengembangan produk dan pengolahan produk sudah tidak diragukan lagi. Oleh karena itu kami berharap dengan adanya kegiatan Program Dimas ini dapat membantu mereka dalam hal penyusunan dan perencanaan kegiatan yang lebih baik.

Permasalahan yang sedang dihadapi oleh kelompok Ibu-lbu rumah tangga yang diberi nama Kelompok Usaha "Kartini" yaitu: 1) sistem pembukuan yang masih sangat sederhana, sehingga tidak rapi dan tidak ada pencatatan cash flow dan laporan laba rugi yang jelas, 2) sistem penerimaan order yang masih tidak jelas, sehingga terkadang ada beberapa orderan yang hilang, dan 3) pengembangan pemasaran yang masih dari kalangan teman, saudara dan tetangga, belum secara 
luas. Kompleksitas permasalahan yang dihadapi oleh Kelompok Usaha "Kartini" saat ini, maka perlu adanya prioritas terhadap permasalahan yang akan segera diatasi dan sekaligus menjadi tujuan dari kegiatan ini, yaitu: 1) masalah manajemen keuangan, dan 2) manajemen usaha.

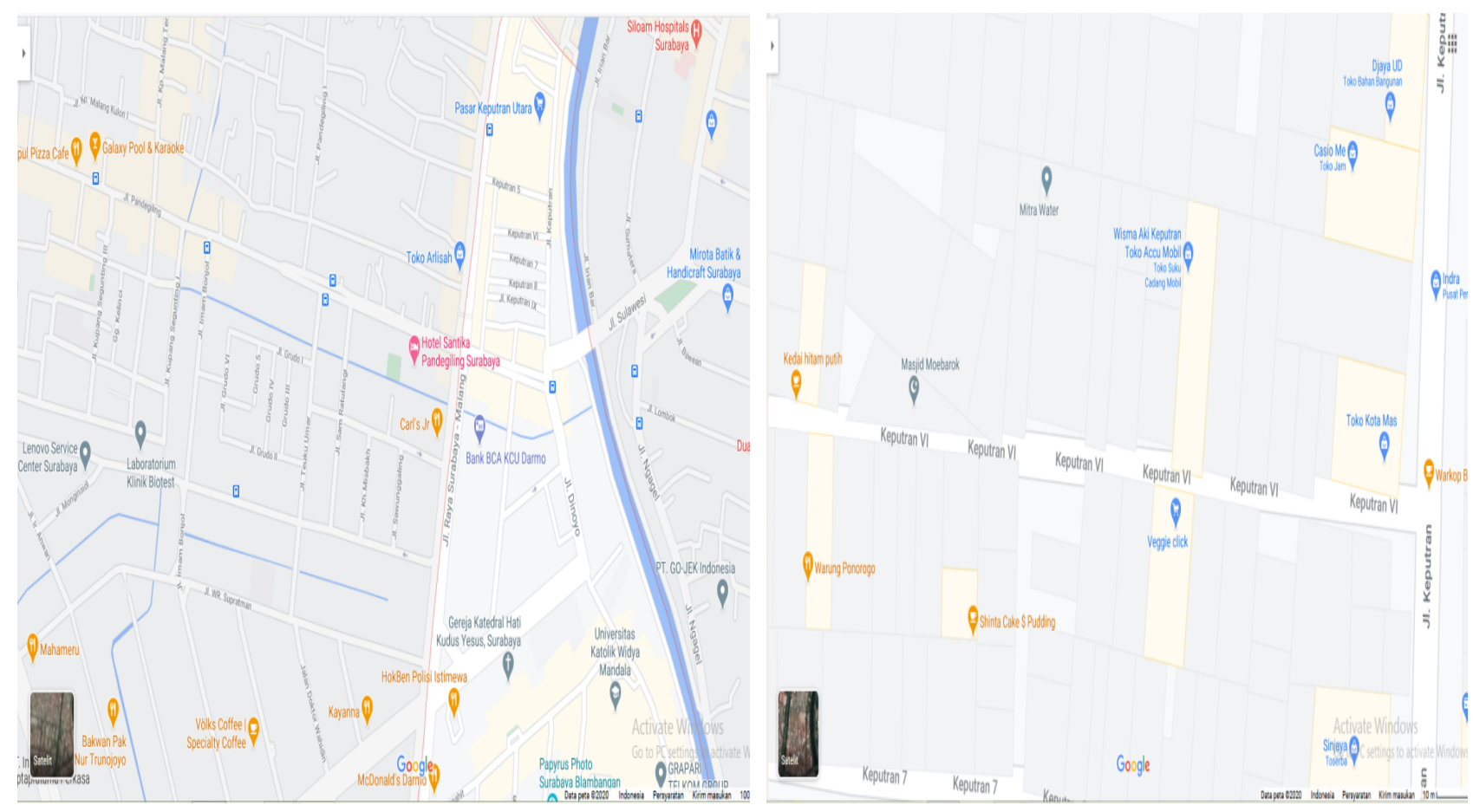

Gambar 1. Peta lokasi Kegiatan Pengabdian Masyarakat di Wilayah Keputran, Kecamatan Tegalsari, Kota Surabaya

Berdasarkan UU No. 20 Tahun 2008 mengenai usaha mikro kecil \& menengah menerangkan bahwa: 1) usaha mikro dapat diartikan sebagai kegiatan usaha yang produktif atas kepemilikan orang perorangan atau badan usaha perorangan sesuai dengan ketentuan yang diatur dalam UU ini; 2) usaha kecil merupakan aktivitas usaha ekonomi yang produktif dan berdiri sendiri, kegiatan usaha ini dilakukan oleh orang perorangan atau badan usaha bukan cabang perusahaan yang dimiliki serta sesuai dengan ketentuan yang berlaku dalam UU ini; dan 3) usaha menengah adalah usaha ekonomi produktif yang berdiri sendiri dan kegiatan usaha ini kerjakan oleh orang perorangan atau badan usaha bukan merupakan anak perusahaan atau cabang perusahaan yang dimiliki baik langsung maupun tidak langsung serta sesuai dengan ketentuan yang sudah ditetapkan dalam UU ini.

Masalah manajemen terdapat beberapa tahapan yang perlu diperhatikan dalam upaya menjalankan manajemen usaha diantaranya (1) mengidentifikasi peluang usaha, tahap awal yang perlu dilakukan adalah proses merencanakan usaha, tahapan ini sangat penting terutama bagi pengusaha baru. Hal ini dapat diartikan sebagai kesiapan para wirausaha dalam dunia usaha dengan segala 
resikonya; (2) melakukan kajian manajemen, faktor sumber daya manusia merupakan kunci dalam menentukan usaha yang akan dijalankan karena SDM memiliki peran strategis dalam proses kegiatan usaha, maka sudah sebuah keharusan SDM dipersiapkan dengan baik. Sudah banyak contoh dari usaha yang mengalami kegagalan dan faktor utamanya adalah SDM karena kita tidak dapat mengelola usaha melalui orang lain yang kita kontrol; (3) melakukan analisa pasar, ruang lingkup dalam analisa ini meliputi kajian terhadap konsumen, sehingga perlu mengklasifikasi segmen pasar apa yang menjadi sasaran konsumen dari produk/jasa yang akan dijalankan dan kita dapat melihat luasnya cukup dari sasaran produk/jasa yang akan dijalankan; (4) melakukan kajian capital, studi mengenai modal meliputi dari mana sumber dana usaha berasal. Apakah 100\% modal pemilik, apakah hutang (bank, pihak lain), ataukah kerjasama dengan pihak lain. Demikian pula dengan besarnya modal yang digunakan untuk membuka usaha, apakah diperlukan modal yang sangat besar, sedang, atau cukup dengan modal kecil. Setelah mengetahui seberapa besar modal yang diperlukan, baru ditentukan apakah modal tersebut cukup didanai dari modal pemilik saja ataukah perlu meminjam dari pihak lain; (5) melakukan kajian persaingan, studi mengenai persaingan meliputi analisis kompetitor yang juga bermain di lahan yang sama. Terdapat beberapa bentuk formal dari business plan: 1) halaman depan; 2) daftar isi; 3) rangkuman eksekutif; 4) penjelasan tentang perusahaan; 5) pemasaran; 6) barang dan jasa yang dihasilkan; 7) usaha meningkatkan penjualan; 8) permodalan; dan 9) kelengkapan dokumen tambahan yang dibutuhkan dalam usaha.

Menurut Handoko et al. (2012) menjelaskan bahwa manajemen merupakan sesuatu hal yang bekerja dengan beberapa orang dalam rangka menentukan dan melaksanakan serta mencapai tujuan sebuah organisasi melalui fungsi diantaranya (Handoko et al., 2012): 1) perencanaan; 2) pengorganisasian; 3) penyusunan personalia; 4) pengarahan; 5) kepemimpinan; dan 6) pengawasan. Lebih lanjut, manajemen adalah sekumpulan proses/tindakan yang meliputi: 1) perencanaan; 2) organisasian; 3) pengarahan; 4) kepemimpinan; dan 5) pengendalian terhadap segala sumber daya organisasi untuk mencapai tujuan sehingga manfaatnya bisa dirasakan oleh manusia (Wahjono, 2015).

Secara teori, manajemen keuangan dapat diartikan segala bentuk aktivitas yang berkaitan dengan a) perolehan; b) pendanaan; dan c) pengelolaan aktiva untuk mencapai tujuan yang sudah ditetapkan (Shaferi \& Handayani, 2014), sedangkan Hartati (2014) menjelaskan bahwa seluruh aktivitas/proses tersebut dilaksanakan hanya demi memaksimalkan pendapatan dari perusahaan dengan meminimalkan biaya, mengingat tindakan alokasi dana yang efisien dalam perusahan secara otomatis mampu memaksimalkan nilai keuangan perusahaan tersebut (Hartati, 2013).

Terdapat beberapa fungsi manajemen keuangan dalam suatu perusahaan diantaranya (Hartati, 2013); (a) proses pencarian dana (Obtain Of Fund), aktivitas ini tercermin dari proses keputusan investasi yang menghasilkan keuntungan terhadap 
perusahaan; (b) proses alokasi dana (Allocation Of Fund), maksud dari proses ini adalah pengelolaan dana dalam segala aktivitas perusahaan. Ada 4 (empat) fungsi manajemen keuangan dalam kegiatan perusahaan, diantaranya (Shaferi \& Handayani, 2014), (a) perencanaan keuangan perusahaan, proses ini merupakan tahap kegiatan peramalan keadaan yang mungkin terjadi dimasa depan dengan kemungkinan berdampak pada pencapaian dari beberapa tujuan perusahaan. Tahap berikutnya, dilakukan proses perencanaan keuangan perusahaan, biasanya dilakukan perencanaan keuangan dalam jangka pendek dan jangka panjang; (b) keputusan permodalan, investasi dan pertumbuhan, selain yang sudah disebutkan sebelumnya, manajemen keuangan juga memiliki fungsi dalam penghimpunan dana sesuai kebutuhan perusahaan dalam berinvestasi jangka waktu pendek/panjang. Selain itu, manajemen keuangan juga berfungsi sebagai penentu pertumbuhan perusahaan di bidang penjualan; (c) proses pengendalian, manajemen keuangan dalam hal ini dapat diartikan proses untuk mengendalikan (Controller) kegiatan operasi dari perusahaan dengan harapan segala kegiatan perusahaan bisa berjalan secara efisien dan efektif sesuai perencanaan yang telah dibuat sebelumnya; (d) manajemen keuangan dengan pasar modal, dalam kegiatan ini manajemen keuangan berfungsi untuk menghubungkan antara perusahaan dan sektor pasar modal dengan harapan perusahaan tersebut mampu melakukan berbagai alternatif sumber-sumber pendanaan yang berasal dari pasar modal.

Tujuan dari kegiatan manajemen keuangan merupakan proses kegiatan yang dilakukan untuk mencapai efisien dan efektif dari keuangan perusahaan. Efisiensi manajemen keuangan merupakan tindakan yang mengarah pada memaksimalkan input dan output, dalam konteks keuangan dapat diartikan proses masuk dan keluarnya uang. Sedangkan efektifitas manajemen keuangan merupakan kegiatan yang mencerminkan seberapa jauh perusahaan bisa mencapai tujuan yang sudah ditentukan sebelumnya oleh perusahaan. Selanjutnya, Untuk pelaksanaan segala kegiatan atau program dan keuangan dilakukan sesuai dengan ketentuan yang berlaku, sehingga jika tahapan tersebut sudah dilakukan dengan benar maka secara otomatis efisiensi dan efektifitas manajemen keuangan dapat mencapai (Marbun \& Situmeang, 2013).

Kegiatan analisa keuangan merupakan proses dasar manajemen keuangan karena dari tahapan ini mampu menjelaskan mengenai kondisi keuangan perusahaan dimasa lalu, saat ini, dan yang akan datang. Informasi tersebut dapat digunakan sebagai bahan pertimbangan dalam mengambil keputusan bagi para manajer di perusahaan tersebut. Sedangkan kerangka dasar dari manajemen keuangan meliputi perencanaan, pencatatan, pelaporan, pengendalian (Bugis, 2018).

\section{Metode}

Metode yang digunakan dalam kegiatan pengabdian masyarakat ini adalah metode partisipasi aktif dalam proses pendampingan dan pelatihan pembuatan dan 
penyusunan pengelolaan keuangan dengan perhitungan sederhana serta penggunaan aplikasi keuangan sebagai pegagan untuk membekali keterampilan kelompok usaha "KARTINI" di wilayah Keputran, Kecamatan Tegalsari, Kota Surabaya adalah sebagai berikut; (1) menyusun atau menyiapkan materi tentang pembukuan sederhana; (2) melakukan sosialisasi, motivasi dan gambaran tentang Model Keuangan UKM Sederhana; (3) pendampingan dan pelatihan tentang pembukuan sederhana sebagai sarana pencatatan yang lebih baik; (4) pendampingan dan Pelatihan Perhitungan HPP dan Bagaimana cara melakukan Pemasaran; (5) Pendampingan dan Pendampingan Pengenalan Aplikasi Keuangan "Warung Umat"; (6) Mendapatkan umpan balik dari peserta pelatihan dan saran mereka tentang hasil pelatihan pembuatan laporan keuangan sederhana yang telah dilakukan atau evaluasi hasil.

\section{Hasil}

Jumlah peserta penyuluhan pada kegiatan ini yakni 10 orang yang merupakan ibu-ibu anggota Kelompok Usaha "KARTINI". Sementara anggota pengabdi terdiri dari 3 orang dosen dan 2 orang mahasiswa yang berasal dari program studi ekonomi pembangunan Universitas Pembangunan Nasional "Veteran" Jawa Timur. Para peserta penyuluhan dan pelatihan sangat antusias terhadap materi yang disampaikan juga pada saat diskusi turut berperan aktif terhadap ceramah yang disampaikan para pemateri. Peran aktif ini menjadi tanda bahwa materi yang disampaikan menarik dan dapat diterima oleh ibu-ibu Kelompok Usaha "KARTINI". Selain itu diharapkan para peserta dapat menerapkan materi penyuluhan dan pelatihan yang diajarkan untuk mengembangkan usaha yang sudah ada untuk lebih luas lagi dalam pemasarannya dan lebih baik lagi dalam pengelolaan keuangannya. Pengetahuan mengenai pengelolaan keuangan yang benar, pencatatan keuangan yang sederhana, perhitungan HPP yang sederhana dan pengenalan aplikasi keuangan sederhana "Warung Umat".

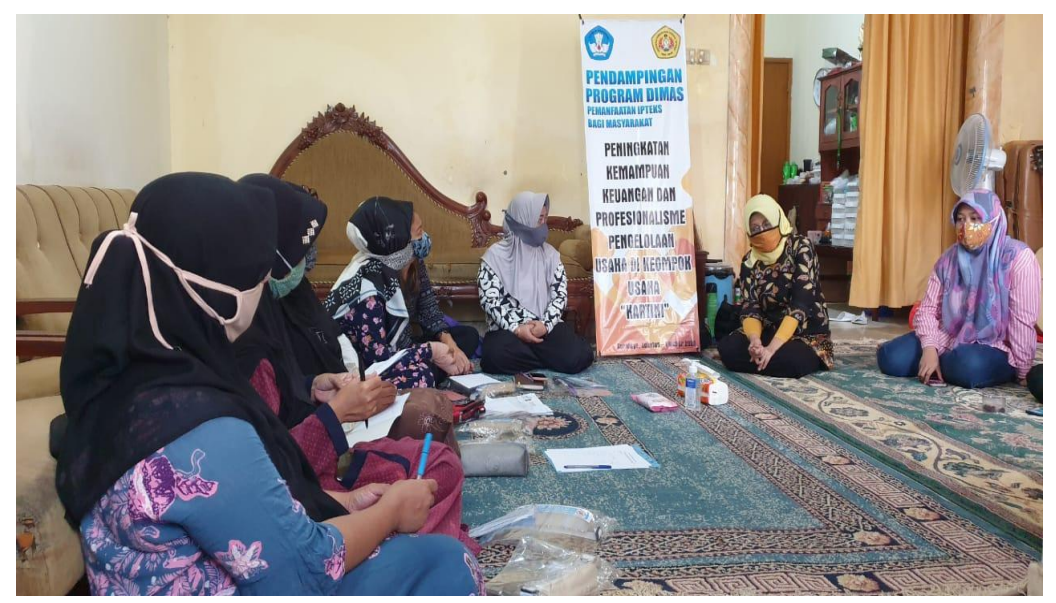

Gambar 2. Penyampaian Materi Pelatihan Pengelolaan Keuangan Sederhana 

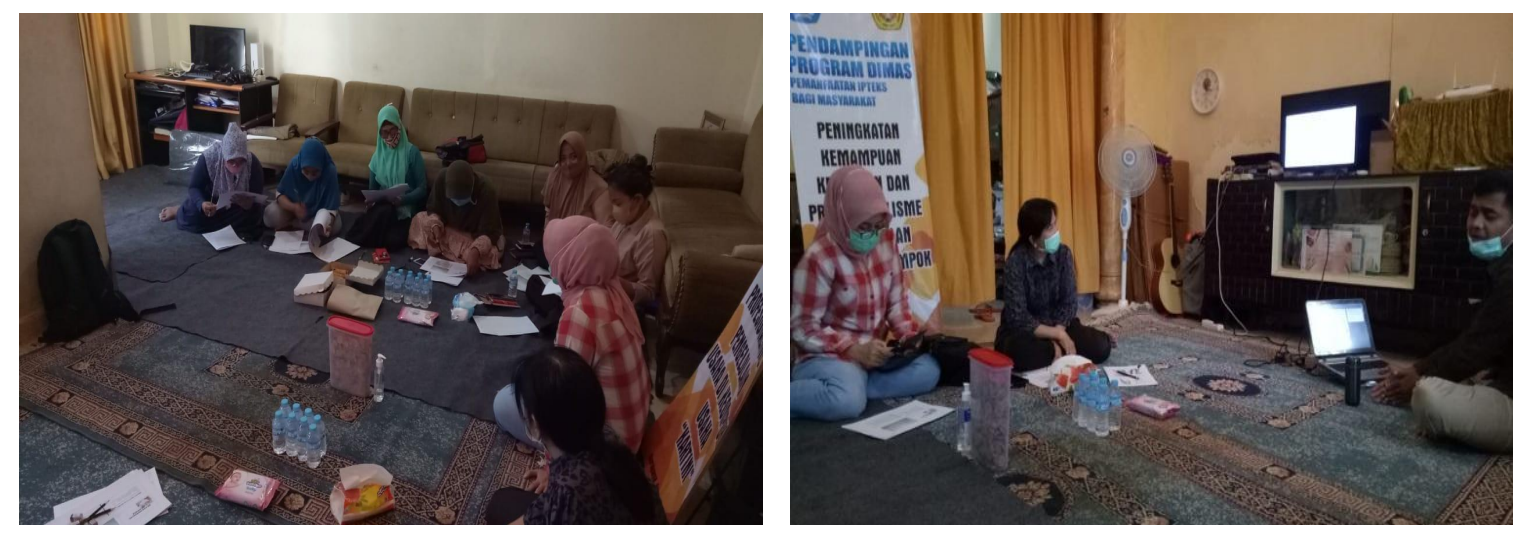

Gambar 3. Pelatihan Perhitungan HPP
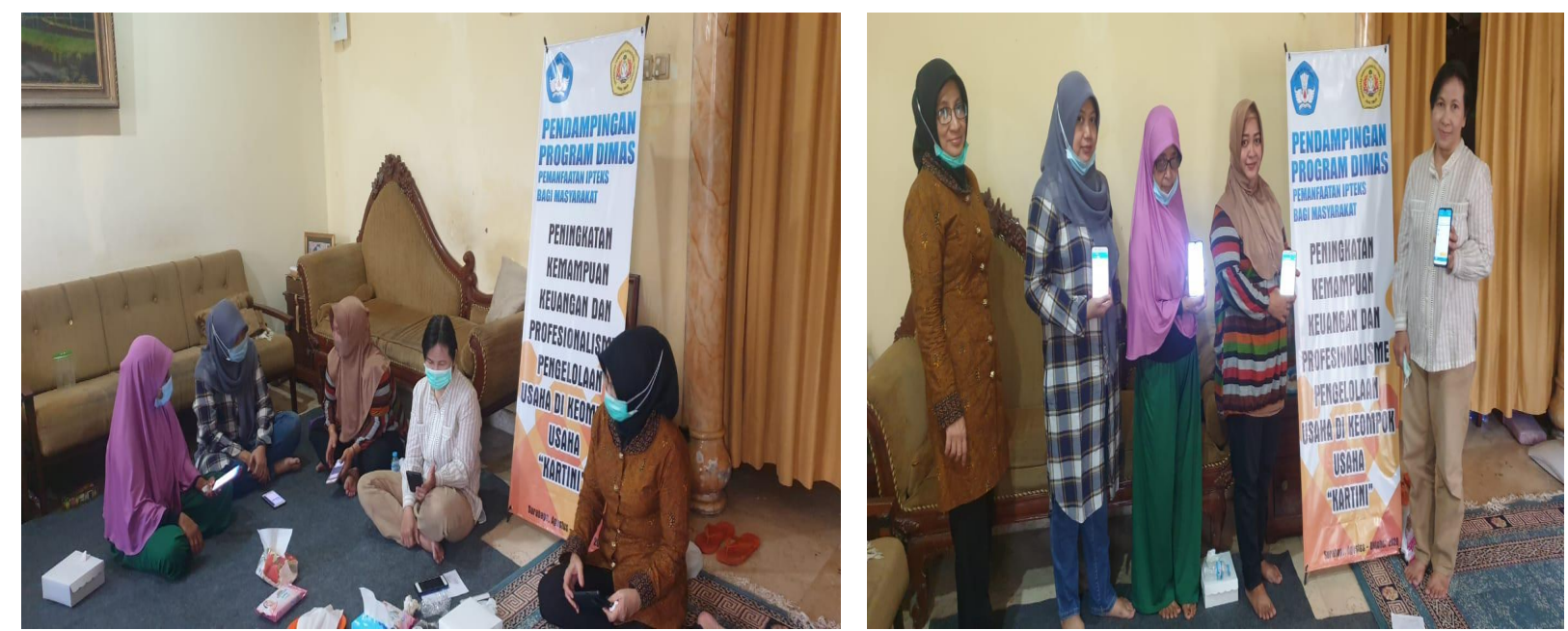

Gambar 4. Pelatihan dan Pengenalan Aplikasi Perhitungan Sederhana

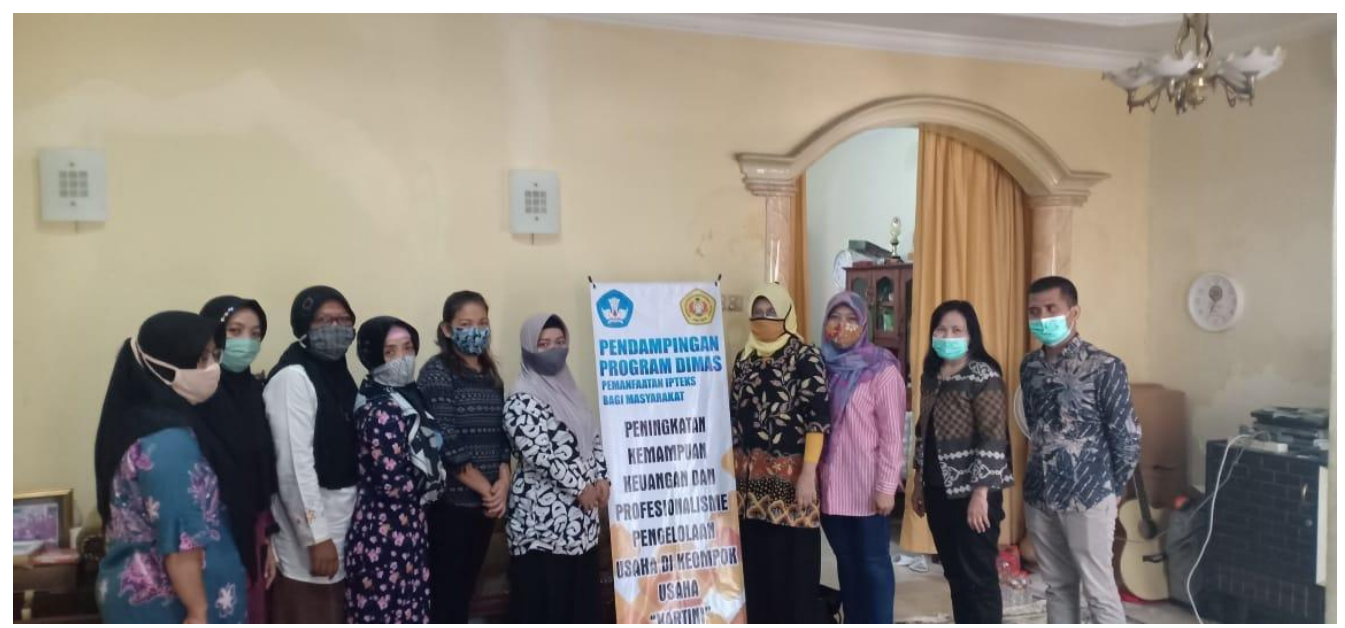

Gambar 5. Foto Bersama Pendampingan dan Penyuluhan 


\section{Diskusi}

Pelaksanaan kegiatan ini diikuti oleh para ibu-ibu kelompok usaha "KARTINI" yang diberikan pelatihan dan materi tentang bagaimana membuat catatan sederhana mengenai laporan keuangan untuk mengetahui kondisi keuangan usaha/bisnis yang dijalankan. Diharapkan mereka akan terbiasa melakukan pembuatan laporan keuangan untuk usahanya UKM Kartini. Dengan adanya pelatihan dan pendampingan dari tim pengabdian kami ibu-ibu kelompok "KARTINI" juga diberikan bagaimana cara penggunaan aplikasi "Warung Umat", aplikasi ini diharapkan dapat membantu dalam pencatatan keuangan dan produk yang mereka miliki.

\section{Kesimpulan}

Didasarkan hasil dari pengamatan untuk pengelolaan keuangan aliran kas dan keuangan penjualan yang telah dilakukan oleh Kelompok usaha "Kartini" masih masih dihadapkan dengan berbagai permasalahan, diantaranya: 1) manajemen Usaha yang kurang tertata dengan baik; dan 2) sistem pencatatan keuangan usaha yang belum teratur dan rapi. Persepsi pelaku UKM "Kartini" terhadap penggunaan/fungsi dari manajemen keuangan terbilang cukup rendah, fakta ini dibenarkan dari hasil lapangan yang menemukan bahwa kelompok usaha "kartini" belum melakukan pencatatan keuangan secara baik dan benar sesuai dengan standar yang ada mulai dari pencatatan penerimaan, pencatatan pengeluaran, penyusunan laporan laba rugi, dan pencatatan penerimaan/pengeluaran kas. Lebih lanjut, anggapan dari anggota tidak melakukan laporan keuangan karena merasa menyulitkan, membuang waktu saja (percuma), butuh tambahan biaya untuk pembuatan laporan keuangan. Selamat para pelaku usaha fokus pada peningkatan kinerja usahanya melalui penerapan inovasi pada produk-produknya dan peningkatan omset penjualan. Sedangkan faktor modal yang minim, persaingan yang ketat antar pelaku usaha, tempat usaha yang belum memadai menjadi penghambat utama dari kinerja kelompok usaha "kartini" selama ini. Disamping itu, hasil evaluasi setelah dilakukan kegiatan pendampingan pada kelompok usaha "Kartini" para anggota sudah mengerti dan mampu melakukan manajemen keuangan dengan baik dan benar, misalnya: 1) menghitung harga pokok penjualan, 2) melakukan pencatatan/pembukuan setiap transaksi; 3) membuat laporan keuangan sederhana (pencatatan secara manual); dan 4) menerapkan software keuangan yang sangat praktis dengan nama Warung Umat.

\section{Pengakuan/Acknowledgements}

Kami sampaikan ucapan terimakasih kepada pihak-pihak yang sudah terlibat dalam pelaksanaan aktivitas kegiatan program Dimas Pemanfaatan IPTEKS Bagi Masyarakat (PIKAT). Kepada anggota tim PIKAT, mahasiswa dan pihak kampus UPN Veteran Jawa Timur, dan tentunya pihak peserta yaitu anggota kelompok 
usaha "KARTINI" Keputran Surabaya yang telah mewujudkan sampai terlaksananya pelatihan dan pendampingan ini. Serta kami ucapkan terimakasih kepada semua pihak yang telah membantu, karena tidak bisa kami sebutkan satu persatu, sehingga pelatihan ini dapat berjalan sesuai dengan harapan.

\section{Daftar Referensi}

Bugis, B. (2018). Faktor-Faktor Yang Mempengaruhi Pengusaha Kecil/Menengah Tidak Menata Keuangan Sesuai Standar Akuntansi Yang Benar. Mega Aktiva: Jurnal Ekonomi Dan Manajemen, 6(1), 28-38. https://doi.org/10.32833/majem.v6i1.45

Handoko, S., Hestiningsih, I., Afif, A. A., \& Mohammad, M. (2012). Sistem Informasi Manajemen Untuk Pengelolaan Kafe. Jurnal Informatika Ahmad Dahlan, 6(1), 102749.

Hartati, S. (2013). Manajemen Keuangan untuk Usaha mikro, kecil dan menengah.

Marbun, H. A. H., \& Situmeang, C. (2013). Financial Distress dan Corporate Turnaround. SNA 17 Mataram, 28.

Shaferi, I., \& Handayani, S. R. (2014). Identifikasi Pengelolaan Keuangan Terhadap Peluang Usaha Online. Sustainable Competitive Advantage (SCA), 4(1), Article 1. http://www.jp.feb.unsoed.ac.id/index.php/sca-1/article/view/722

Wahjono, S. I. (2015). Manajemen sumber daya manusia. Salemba Empat. 